\title{
Neurological diseases in Peru: a systematic analysis of the global burden disease study
} Enfermedades neurológicas en el Perú: un análisis sistemático del Global Burden Disease Study

\author{
Carlos ALVA-DÍAZ1, Andrely HUERTA-ROSARIO2,3,4, Kevin PACHECO-BARRIOS ${ }^{5,6}$,
}

Roberto A. MOLINA',3,4, Alba NAVARRO-FLORES 2,3,4, Wilfor AGUIRRE-QUISPE',

Nilton CUSTODIO ${ }^{8}$, Juan TORO-PEREZ ${ }^{9}$, Nicanor MORI ${ }^{4}$, Roberto ROMERO-SANCHEZ ${ }^{4}$

\begin{abstract}
Background: Disease burden indicators assess the impact of disease on a population. They integrate mortality and disability in a single indicator. This allows setting priorities for health services and focusing resources. Objective: To analyze the burden of neurological diseases in Peru from 1990-2015. Methods: A descriptive study that used the epidemiological data published by the Institute for Health Metrics and Evaluation of Global Burden of Diseases from 1990 to 2015. Disease burden was measured using disability-adjusted life years (DALY) and their corresponding 95\% uncertainty intervals (UIs), which results from the addition of the years of life lost (YLL) and years lived with disability (YLD). Results: The burden of neurological diseases in Peru were 9.06 and 10.65\%, in 1990 and 2015, respectively. In 2015, the main causes were migraine, cerebrovascular disease (CVD), neonatal encephalopathy (NE), and Alzheimer's disease and other dementias (ADD). This last group and nervous system cancer (NSC) increased 157 and 183\% of DALY compared to 1990, respectively. Young population ( 25 to 44 years old) and older (>85 years old) were the age groups with the highest DALY. The neurological diseases produced 11.06 and $10.02 \%$ of the national YLL (CVD as the leading cause) and YLD (migraine as the main cause), respectively. Conclusion: The burden of disease (BD) increased by $1.6 \%$ from 1990 to 2015 . The main causes were migraine, CVD, and NE. ADD and NSC doubled the DALY in this period. These diseases represent a significant cause of disability attributable to the increase in the life expectancy of our population among other factors. Priority actions should be taken to prevent and treat these causes.
\end{abstract}

Keywords: Cost of Illness; Neurology; Epidemiology.

\section{RESUMEN}

Introducción: Los indicadores de carga de la enfermedad evalúan el impacto que producen las enfermedades en una población. Integran la mortalidad y discapacidad en un solo indicador. Esto permite fijar prioridades para los servicio de salud y enfocar los recursos. Objetivo: Analizar los datos de carga de enfermedades neurológicas en Perú para el periodo 1990-2015. Métodos: Estudio descriptivo de datos del The Institute for Health Metrics and Evaluation de carga de enfermedad global desde el año 1990 al 2015. La medida de carga de la enfermedad utilizada fue los años de vida ajustados por discapacidad y sus correspondientes intervalos de incertidumbre (95\%), que resultan de la suma de los años de vida perdidos debido a muerte prematura y los vividos con discapacidad. Resultados: La carga de enfermedades neurológicas en Perú fue de 9,06 y 10,65\% en 1990 y 2015, respectivamente. En 2015, las principales causas fueron: migraña, enfermedad cerebrovascular, encefalopatía neonatal, enfermedad de Alzheimer y otras demencias. Este último grupo y el cáncer del sistema nervioso presentaron un incremento del 157 y $183 \%$ de los años de vida ajustados por discapacidad con respecto a 1990, respectivamente. Los adultos jóvenes (25 a 44 años) y adultos mayores (>85 años) fueron los grupos de edad con más años de vida ajustado por discapacidad. Las enfermedades neurológicas produjeron el 11.06 y el $10.02 \%$ de los años de vida perdidos debido a muerte prematura (enfermedad cerebrovascular como la causa principal) y años

\footnotetext{
${ }^{1}$ Universidad Científica del Sur, Facultad de Ciencias de la Salud, Lima, Perú.

${ }^{2}$ Hospital Daniel Alcides Carrión, Servicio de Neurología, Departamento de Medicina y Oficina de Apoyo a la Docencia e Investigación (OADI), Callao, Perú.

${ }^{3}$ Red de Eficacia Clínica y Sanitaria, REDECS, Lima, Perú.

«Universidad Nacional Federico Villarreal, Facultad de Medicina Hipólito Unanue, Lima, Perú.

5SYNAPSIS Mental Health and Neurology, Non-Profit organization, Lima, Peru.

${ }^{6}$ Universidad San Ignacio de Loyola, Unidad de Investigación para la Generación y Síntesis de Evidencias en Salud, Lima, Perú.

${ }^{7}$ Instituto Nacional de Ciencias Neurológicas, Lima, Perú.

${ }^{8}$ Instituto Peruano de Neurociencias, Lima, Perú.

${ }^{9}$ Hospital Nacional Guillermo Almenara, Departamento de Clínica Pediátrica, Lima, Perú.

Carlos ALVA-DÍAZ (iD https://orcid.org/0000-0003-3584-7298; Andrely HUERTA-ROSARIO iD https://orcid.org/0000-0003-1160-6641; Kevin PACHECO-BARRIOS (ID https://orcid.org/0000-0002-7166-2816; Roberto A. MOLINA (DD https://orcid.org/0000-0003-1547-077X; Alba NAVARRO-FLORES (iD https://orcid.org/0000-0001-8415-619x; Wilfor AGUIRRE-QUISPE (iD https://orcid.org/0000-0002-6677-0900; Nilton CUSTODIO (D) https://orcid.org/0000-0002-8025-3272; Juan TORO-PEREZ (D) https://orcid.org/0000-0002-0195-6966; Nicanor MORI (iD https://orcid.org/0000-0002-2270-1663; Roberto ROMERO-SANCHEZ (iD) https://orcid.org/0000-0002-2761-1800

Correspondence: Andrely Huerta-Rosario; Hospital Daniel Alcides Carrión, Servicio de Neurología, Departamento de Medicina y Oficina de Apoyo a la Docencia e Investigación (OADI), Jr Libra 114 Urb Mercurio Bajo Los Olivos Lima 10, Peru; E-mail: lynatario@gmail.com

Conflict of interest: There is no conflict of interest to declare.

Received on August 11, 2019; Received in its final form on January 15, 2020; Accepted on January $29,2020$.
} 
vividos con discapacidad (migraña como la causa principal), respectivamente. Conclusiones: La carga de la enfermedad aumentó un 1,6\% entre 1990 y 2015. Las principales causas fueron migraña, la enfermedad cerebrovascular y la encefalopatía neonatal. La enfermedad de Alzheimer y otras demencias y cáncer del sistema nervioso duplicaron los años de vida ajustados por discapacidad en este período. Estas enfermedades representan una causa importante de discapacidad atribuible al aumento de la esperanza de vida de nuestra población, entre otros factores. Se deben tomar medidas prioritarias para prevenir y tratar estas causas.

Palabras clave: Costo de Enfermedad; Neurología; Epidemiología.

Classically, the impact of diseases on populations has been represented by frequency indicators, such as prevalence, incidence, or mortality; however, the impact is currently being measured with the burden of disease (BD) approach ${ }^{1}$. The BD indicators complement and overcome some of the limitations of frequency indicators, bringing together the fatal and non-fatal consequences of diseases, integrating them into a single indicator ${ }^{2,3}$. The essential objectives of BD studies are ${ }^{4}$ :

- To help setting the priorities of health services, therefore, setting resources for their execution.

- To establish health research priorities.

- To identify disadvantaged groups and focus on health interventions.

- To offer a comparable measure to evaluate and plan interventions and programs in public health ${ }^{4,5}$.

According to the Global Burden of Disease (GBD) Study, the most important $\mathrm{BD}$ indicator is the number of disabilityadjusted life year (DALY) lost, which is a year of healthy life lost (including premature death or disability). The number of DALYs is the result of adding the years of life lost (YLL) and years lived with disability (YLD) $)^{6,7}$.

As suggested in the GBD report, a more detailed exploration of the differential trends by region or country is justified, which could provide valuable information for decision-making processes and health resources allocation to modify the social determinants, risk factors, and reduce the $\mathrm{BD}^{5}$. In Peru, there is a first national study carried out by Velasquez et al. on the BD from 2004 to 2008, which initiates a series of studies with these indicators ${ }^{1}$. They reported that neuropsychiatric diseases were the group with the highest BD estimates, including stroke, dementia, epilepsy, and Parkinson's disease (PD) ${ }^{1}$. However, not all the neurological diseases have been evaluated to recognize their BD impact and trends in Peru. This lack of information holds back the prioritization of national health policies on the topic.

In this systematic analysis, we quantify the BD due to neurological conditions and its variation from 1990 to 2015 in Peru according to gender, age groups, and type of disease.

\section{METHODS}

This systematic analysis is based on information from the GBD 2015, which collects data on more than 300 causes of mortality in 519 geographic locations, distributed throughout
195 countries and 21 regions. The BD was expressed according to the number of DALYs, evaluated according to each cause, geographical location, age group, and gender. Population was stratified into 17 groups by age, with intervals of 4 years; the first group included children between 1 to 4 years old, and the last group comprised those over 85. Besides that, comparisons of the BD were made between 1990 and 2015 according to the percentage of change $e^{6,7}$.

Just like in previous studies ${ }^{5,8}$, we analyzed the results for various neurological diseases, defined by the Diagnostic and Statistical Manual of Mental Disorders (DSM-IV) and the International Classification of Diseases (ICD-10), in Peru ${ }^{3,4}$. Diseases were divided into groups according to the GBD classification. The GBD 2015 study included the following neurological disorders: Alzheimer's disease and other dementias (ADD), PD, epilepsy, multiple sclerosis (MS), motor neuron disease (MND), migraine, tension-type headache (TTH), headache due to overuse of medication $(\mathrm{MOH})$ and a category for other neurological diseases that included muscular dystrophy and Huntington's disease. Meningitis, encephalitis, nervous system cancer (NSC), neonatal encephalopathy (NE) due to asphyxia or trauma at birth, and cerebrovascular disease (CVD), both ischemic and hemorrhagic, were included, despite they were not included in the neurological disorders list reported by the GBD 2015.

\section{Extraction data}

Two trained members of the research team performed the extraction independently. First, they accessed the GBD website (http://www.healthdata.org/), selected the data visualization option, selected filters by neurological diseases and related conditions, and downloaded it. Later, they tabulated the estimates in Microsoft Excel 2017 for data description and for the creation of the graphics analysis. Results were reported as DALYs average with their corresponding 95\% uncertainty intervals (UIs).

\section{Estimation of burden of disease indicators}

\section{Disability-adjusted life year}

To estimate the number of DALYs, the methodology described in the GBD (2015) study was followed'. According to them, the disability-adjusted life years (DALY) are the result of adding the YLL and years lived with disability (YLD). The data used to estimate YDL and YLL and were obtained from the systematic review of databases and literature of 85 causes of 
disease published until October $31^{\text {st }}$, 2015. Information was systematically examined from surveys archived in the Global Health Data Exchange platform, sources suggested by experts in the countries, and national surveys identified in the main data catalogs of multinational surveys or the websites of the Peruvian Ministry of Health and Statistics Office ${ }^{9}$.

\section{Years of life lost}

The YLLs are the years of life lost due to a premature death and result from multiplying the mortality rate due to an illness by the life expectancy at each age group based on an ideal standard. The latter was calculated according to the West 26 Model developed by Coale et al. ${ }^{10}$, which makes standard life tables considering the life expectancy by country. The number of deaths was obtained from death records in Peru if the disease is the main cause of death ${ }^{11}$. In our case, the years were lost due to premature mortality from neurological disorders and related conditions.

\section{Years lived with disability}

The YLDs are the years lived with disability due to disease and result from the prevalence of each illness sequela multiplied by the weight of disability adjusted for comorbidities ${ }^{12}$. The weight of the disability is a numerical factor proportional to the severity of the disability that varies from 0 (equivalent to perfect health) to 1 (equivalent to death) ${ }^{13}$. The incidence and prevalence of the diseases by age, gender, disease cause, year, and geographic location were estimated following the recommendations of the Guidelines for Accurate and Transparent Health Estimates Reporting (GATHER) with a confident interval of $95 \%{ }^{9,14}$.

\section{RESULTS}

According to the GBD 2015, the total BD from all causes in Peru in 2015 was 6,287,482.2 DALYs. Neurological diseases accounted for $10.64 \%$, showing an increase of $1.6 \%$ compared to 1990. Regarding gender, neurological disorders in women contributed a greater proportion than men of the total DALYs. In women, the highest proportion of DALYs was produced by migraine, $\mathrm{ADD}, \mathrm{MOH}$, and TTH. In men, they were mainly due to CVD, NE, and epilepsy (Table 1).

Regarding the components of the DALYs in Peru (YLLs and YLDs), the total YLDs for all diseases were 3,047,293.80 in 2015 , and neurological disorders accounted for $10.2 \%$ of the total YLDs in Peru, with migraine and $\mathrm{MOH}$ being the main causes, and women contributed to a higher proportion. In the same year, the total YLLs in Peru were 3,240,188.38, and neurological diseases accounted for $11.06 \%$ of the total, with CVD and NE being the main causes, and men contributed to greater proportion in that year (Table 2).

The first five causes of DALYs in 1990 were migraine, CVD, NE, epilepsy, and meningitis. In 2015, the first three causes remained in the same place, but the $\mathrm{ADD}$ and the $\mathrm{MOH}$ ranked $4^{\text {th }}$ and $5^{\text {th }}$, and epilepsy and meningitis ranked $6^{\text {th }}$ and $8^{\text {th }}$, respectively. Migraine ranked first in both years; besides that, it showed an increase of $57 \%$ of DALYs. Significant increases were presented for ADD (157\%) and NSC (183\%) and decreases in meningitis, encephalitis, and epilepsy in 2015 compared to 1990. Likewise, the last three causes of DALYs for 1990 and 2015 were PD, MS, and MND (Table 3).

The variation of the DALYs due to neurological diseases by age and gender showed that the highest levels of DALYs occur between 20 to 44 years old and in the older population (over 85 years old). Neurological diseases in women produced a higher amount of DALYs in all age groups (Figure 1).

The distribution of DALYs for each neurological disease and age group showed that the burden produced by migraine began in childhood, increased in youth, and adulthood and decreased markedly in the elderly. A similar pattern followed $\mathrm{MOH}$ and epilepsy. CVD increased progressively throughout life and ADD as well, especially in the last decades of life. MS, encephalitis, CNS, meningitis, and EN showed a negative tendency from childhood and adulthood to elderly (Figure 2).

\section{DISCUSSION}

Our study identified a significant increase in the DALYs between 1990 and 2015 due to neurological disorders, producing more than $10 \%$ of all DALYs in Peru and more than 9\% of the total YLDs in 2015. This proportion is like that from a previous study, in which neurological disorders represent $10.2 \%$ worldwide DALYs ${ }^{5}$. Moreover, the proportion of YLDs was estimated to increase worldwide, from $21.1 \%$ in 1990 to $31.2 \%$ in 2013 , due to musculoskeletal, mental, neurological disorders and chronic respiratory diseases, which have been associated to populational growth and aging ${ }^{15}$. Our results are consistent with these previous findings.

According to the GBD study, that estimated the DALYs in the world from 1990 to 2015, headaches are among the eight disorders that affected more than $10 \%$ of the global population in 2015. Migraine, TTH and MOH are the neurological conditions with the most amount of DALYs worldwide ${ }^{5}$, with an increase of 15.3, 15.3, and 18.9\% between 2005 to 2015, respectively ${ }^{6,7}$. The data from Peru also show that DALYs due to headaches have increased for all types reported, migraine in 57\%, $\mathrm{MOH}$ in $77 \%$, and $\mathrm{TTH}$ in $65 \%$. Migraine is the leading cause of the burden for neurological disorders, especially in women. It is essential to recognize that the burden generated by headaches in all reported types is exclusively due to the produced disability; these results founded in Peru are consistent with the global reports ${ }^{6,7}$. Nonetheless, our findings are aligned with the high prevalence of migraine in Peru, with $28.7 \%$ of cases, and with the high estimates in younger women population ${ }^{16}$.

In Peru, the Health Ministry burden report (2004) showed that from 21 disease groups, neuro-psychiatric diseases are 
those with the highest-burden of disease and represent $16 \%$ of all DALYs. From the report, CVDs represented the tenth cause of BD in Peru' ${ }^{1}$. Our study shows that between 1990 and 2015 there has been a decrease in the burden of DALYs due to CVD (-48\%), and this is mainly due to a decrease in YLLs (yet, CVD continues to be the main cause of YLL due to neurological disorders). Similar findings were observed globally, with lower rates in developed countries than in developing countries, between 1990 to $2013^{17}$ and for the GBD report, from 2005 to $2015^{6}$. However, the YLDs due to CVD have almost doubled in the same period, consistent with the global data, between 1990 and 2010, which showed a significant increase of up to $87 \%^{18}$ and an increase of $20.7 \%$ in all its types (ischemic and hemorrhagic) between 2005 and $2015^{7}$ with a greater presence in men, who have more frequent and severe
CVD risk factors ${ }^{19}$. Moreover, our results are consistent with the decrease in mortality rates registered in Peru from 2014 to $2015(11.4$ per 100,000) compared to the period from 2005 to $2006(14.6 \text { per } 100,000)^{20}$.

YLDs for ADD increased by $91.8 \%$ between 1990-2013 worldwide ${ }^{6}$. Dementias were estimated to contribute to $11.2 \%$ of YLDs in people over 60, surpassing vascular and cancer diseases ${ }^{21}$. Globally, dementia is the $49^{\text {th }}$ condition that causes DALYs. In Central America, they ranked $50^{\text {th }}$, and $26^{\text {th }}$ in South America ${ }^{8}$. Our study reveals that after 25 years, the DALYs by ADD increased 157\%, consistent with the reports of other countries in the region, such as in Chile, between 1990 and 2010, which reported an increase of $200 \%{ }^{22}$. This increase occurs both due to disability (YLDs) and premature death (YLLs). In countries such as Cuba, the Dominican Republic

Table 1. Comparison of disability-adjusted life year due to Neurological diseases in Peru, 1990 and 2015 (uncertainty interval 95\%).

\begin{tabular}{|c|c|c|c|c|c|c|}
\hline & $\begin{array}{l}\text { DALYs } 1990 \\
\text { (Both) }\end{array}$ & $\begin{array}{l}\text { DALYs } 1990 \\
\text { (Men) }\end{array}$ & $\begin{array}{l}\text { DALYs } 1990 \\
\text { (Women) }\end{array}$ & $\begin{array}{l}\text { DALYs } 2015 \\
\text { (Both) }\end{array}$ & $\begin{array}{l}\text { DALYs } 2015 \\
\text { (Men) }\end{array}$ & $\begin{array}{l}\text { DALYs } 2015 \\
\text { (Women) }\end{array}$ \\
\hline $\begin{array}{l}\text { Neurological } \\
\text { diseases }\end{array}$ & $\begin{array}{c}815,098 \\
(642,014-102,819,6)\end{array}$ & $\begin{array}{c}414,393 \\
(311,703-536,558)\end{array}$ & $\begin{array}{c}400,704 \\
(298,761-525,297)\end{array}$ & $\begin{array}{c}669,448 \\
(491,385-881,411)\end{array}$ & $\begin{array}{c}306,841 \\
(220,017-411,067)\end{array}$ & $\begin{array}{c}362,607 \\
(256,700-492,729)\end{array}$ \\
\hline Meningitis & $\begin{array}{c}43,448 \\
(36,239-57,151)\end{array}$ & $\begin{array}{c}24,032 \\
(18,912-32,464)\end{array}$ & $\begin{array}{c}19,416 \\
(15,552-26,626)\end{array}$ & $\begin{array}{c}18,469 \\
(13,752-22,529)\end{array}$ & $\begin{array}{c}10,387 \\
(7,252-13,102)\end{array}$ & $\begin{array}{c}8,082 \\
(5,936-10,183)\end{array}$ \\
\hline Encephalitis & $\begin{array}{c}27,775 \\
(23,572-32,717)\end{array}$ & $\begin{array}{c}15,258 \\
(12,487-18,496)\end{array}$ & $\begin{array}{c}12,517 \\
(8,937-16,071)\end{array}$ & $\begin{array}{c}17,966 \\
(15,140-22,765)\end{array}$ & $\begin{array}{c}10,423 \\
(8,403-12,718)\end{array}$ & $\begin{array}{c}7,543 \\
(5,901-11,435)\end{array}$ \\
\hline $\begin{array}{l}\text { Neonatal } \\
\text { encephalopathy } \\
\text { due to asphyxia } \\
\text { or trauma at birth }\end{array}$ & $\begin{array}{c}208,727 \\
(156,688-272,952)\end{array}$ & $\begin{array}{c}112,365 \\
(72,431-158,891)\end{array}$ & $\begin{array}{c}96,363 \\
(62,980-135,268)\end{array}$ & $\begin{array}{c}97,941 \\
(69,593-128,398)\end{array}$ & $\begin{array}{c}53,714 \\
(36,197-73,492)\end{array}$ & $\begin{array}{c}44,228 \\
(29,087-60,773)\end{array}$ \\
\hline $\begin{array}{l}\text { Nervous system } \\
\text { cancer }\end{array}$ & $\begin{array}{c}9,781 \\
(8,111-15,945)\end{array}$ & $\begin{array}{c}5,907 \\
(4,499-11,026)\end{array}$ & $\begin{array}{c}3,874 \\
(3,304-5,184)\end{array}$ & $\begin{array}{c}27,680 \\
(16,094-34,138)\end{array}$ & $\begin{array}{c}13,998 \\
(5,716-19,745)\end{array}$ & $\begin{array}{c}13,682 \\
(9,436-16,576)\end{array}$ \\
\hline $\begin{array}{l}\text { Cerebrovascular } \\
\text { disease }\end{array}$ & $\begin{array}{c}285,884 \\
(255,526-312,053)\end{array}$ & $\begin{array}{c}158,708 \\
(136,006- \\
178,800)\end{array}$ & $\begin{array}{c}127,176 \\
(113,898- \\
139,538)\end{array}$ & $\begin{array}{c}149,448 \\
(132,441-171,734)\end{array}$ & $\begin{array}{c}78,968 \\
(66,688-96,999)\end{array}$ & $\begin{array}{c}70,480 \\
(59,500-82,609)\end{array}$ \\
\hline $\begin{array}{l}\text { Alzheimer } \\
\text { diseases and } \\
\text { other dementias }\end{array}$ & $\begin{array}{c}30,182 \\
(24,878-35,657)\end{array}$ & $\begin{array}{c}13,116 \\
(10,778-15,496)\end{array}$ & $\begin{array}{c}17,065 \\
(14,063-20,308)\end{array}$ & $\begin{array}{c}77,687 \\
(64,739-92,164)\end{array}$ & $\begin{array}{c}32,733 \\
(26,839-39,694)\end{array}$ & $\begin{array}{c}44,954 \\
(36,927-54,184)\end{array}$ \\
\hline $\begin{array}{l}\text { Parkinson } \\
\text { disease }\end{array}$ & $\begin{array}{c}3,198 \\
(2,720-3,756)\end{array}$ & $\begin{array}{c}1,776 \\
(1,488-2,107)\end{array}$ & $\begin{array}{c}1,422 \\
(1,183-1,693)\end{array}$ & $\begin{array}{c}4,324 \\
(3,517-5,442)\end{array}$ & $\begin{array}{c}2,479 \\
(1,983-3,325)\end{array}$ & $\begin{array}{c}1,845 \\
(1,448-2,279)\end{array}$ \\
\hline Epilepsy & $\begin{array}{c}61,191 \\
(43,886-81,779)\end{array}$ & $\begin{array}{c}32,716 \\
(23,616-44,175)\end{array}$ & $\begin{array}{c}28,474 \\
(20,318-38,439)\end{array}$ & $\begin{array}{c}44,826 \\
(30,371-62,495)\end{array}$ & $\begin{array}{c}23,719 \\
(16,393-33,442)\end{array}$ & $\begin{array}{c}21,107 \\
(14,008-30,077)\end{array}$ \\
\hline Multiple sclerosis & $\begin{array}{c}966 \\
(818-1,124)\end{array}$ & $\begin{array}{c}446 \\
(373-521)\end{array}$ & $\begin{array}{c}520 \\
(433-621)\end{array}$ & $\begin{array}{c}1,818 \\
(1,464-2,146)\end{array}$ & $\begin{array}{c}829 \\
(668-985)\end{array}$ & $\begin{array}{c}989 \\
(762-1,200)\end{array}$ \\
\hline Migraine & $\begin{array}{c}104,048 \\
(64,483-155389)\end{array}$ & $\begin{array}{c}31,925 \\
(19,960-47,665)\end{array}$ & $\begin{array}{c}72,123 \\
(44,443-108,014)\end{array}$ & $\begin{array}{c}163,433 \\
(102,106-241,359)\end{array}$ & $\begin{array}{c}50,644 \\
(31,254-74,901)\end{array}$ & $\begin{array}{c}112,789 \\
(70,524-167,407)\end{array}$ \\
\hline $\begin{array}{l}\text { Tensional } \\
\text { Headache }\end{array}$ & $\begin{array}{c}5,465 \\
(2575-10081)\end{array}$ & $\begin{array}{c}1,845 \\
(867-3,446)\end{array}$ & $\begin{array}{c}3,620 \\
(1,699-6,627)\end{array}$ & $\begin{array}{c}9,043 \\
(4,177-16,708)\end{array}$ & $\begin{array}{c}3,121 \\
(1,429-5,735)\end{array}$ & $\begin{array}{c}5,922 \\
(2,749-10,988)\end{array}$ \\
\hline $\begin{array}{l}\text { Medication } \\
\text { overuse for } \\
\text { headache }\end{array}$ & $\begin{array}{c}29,099 \\
(18,600-42,647)\end{array}$ & $\begin{array}{c}12,775 \\
(7,958-18,738)\end{array}$ & $\begin{array}{c}16,324 \\
(10,519-24,101)\end{array}$ & $\begin{array}{c}51,395 \\
(33,321-75,345)\end{array}$ & $\begin{array}{c}22,588 \\
(14,543-33,045)\end{array}$ & $\begin{array}{c}28,807 \\
(18,652-42,438)\end{array}$ \\
\hline $\begin{array}{l}\text { Motoneuron } \\
\text { disease }\end{array}$ & $\begin{array}{c}1,188 \\
(837-1,466)\end{array}$ & $\begin{array}{c}700 \\
(473-907)\end{array}$ & $\begin{array}{c}488 \\
(329-630)\end{array}$ & $\begin{array}{c}1,491 \\
(1,267-1,739)\end{array}$ & $\begin{array}{c}884 \\
(701-1,092)\end{array}$ & $\begin{array}{c}606 \\
(457-749)\end{array}$ \\
\hline $\begin{array}{l}\text { Other } \\
\text { neurological } \\
\text { diseases }\end{array}$ & $\begin{array}{c}4,145 \\
(3,079-5,477)\end{array}$ & $\begin{array}{c}2,824 \\
(1,856-3,826)\end{array}$ & $\begin{array}{c}1,321 \\
(1,101-2,176)\end{array}$ & $\begin{array}{c}3,926 \\
(3,404-4,449)\end{array}$ & $\begin{array}{c}2,355 \\
(1,951-2,791)\end{array}$ & $\begin{array}{c}1,572 \\
(1,313-1,830)\end{array}$ \\
\hline
\end{tabular}

DALYs: disabilities-adjusted life year. 
Table 2. Comparison of years of life lost y years lived with disability due to Neurological diseases in Peru, 1990 and 2015 (uncertainty interval 95\%).

\begin{tabular}{|c|c|c|c|c|}
\hline & YLLs 1990 & YLLs 2015 & YLDs 1990 & YLDs 2015 \\
\hline Neurological diseases & $\begin{array}{c}607,743 \\
(505,172-729,501)\end{array}$ & $\begin{array}{c}358,549 \\
(284,509-439,207)\end{array}$ & $\begin{array}{c}207,353 \\
(129,150-306,850)\end{array}$ & $\begin{array}{c}310,898 \\
(196,914-456,927)\end{array}$ \\
\hline Meningitis & $\begin{array}{c}42,426 \\
(35,179-56,050)\end{array}$ & $\begin{array}{c}17,058 \\
(12,326-21,022)\end{array}$ & $\begin{array}{c}1,022 \\
(712-1,341)\end{array}$ & $1,411(990-1,856)$ \\
\hline Encephalitis & $\begin{array}{c}27,270 \\
(23,070-32,261)\end{array}$ & $\begin{array}{c}17,328 \\
(14,496-22,303)\end{array}$ & $\begin{array}{c}504 \\
(353-672)\end{array}$ & $\begin{array}{c}638 \\
(444-856)\end{array}$ \\
\hline $\begin{array}{l}\text { Neonatal encephalopathy due } \\
\text { to asphyxia or trauma at birth }\end{array}$ & $\begin{array}{c}202,816 \\
(150,195-267,414)\end{array}$ & $\begin{array}{c}89,906 \\
(61,716-120,699)\end{array}$ & $\begin{array}{c}5,911 \\
(3,724-9,197)\end{array}$ & $\begin{array}{c}8,035 \\
(5,123-12,378)\end{array}$ \\
\hline Nervous system cancer & $\begin{array}{c}9,669 \\
(8,006-15,766)\end{array}$ & $\begin{array}{c}27,276 \\
(15,818-33,692)\end{array}$ & $\begin{array}{c}112 \\
(70-184)\end{array}$ & $\begin{array}{c}403 \\
(222-605)\end{array}$ \\
\hline Cerebrovascular disease & $\begin{array}{c}278,810 \\
(248,872-304,010)\end{array}$ & $\begin{array}{c}137,139 \\
(121,933-158,471)\end{array}$ & $\begin{array}{c}7,074 \\
(4,859-9,528)\end{array}$ & $\begin{array}{c}12,309 \\
(8,487-16,661)\end{array}$ \\
\hline $\begin{array}{l}\text { Alzheimer diseases and other } \\
\text { dementias }\end{array}$ & $\begin{array}{c}214,05 \\
(17,834-24,871)\end{array}$ & $\begin{array}{c}52,929 \\
(43,779-62,767)\end{array}$ & $\begin{array}{c}8,777 \\
(6,244-11,839)\end{array}$ & $\begin{array}{c}24,759 \\
(17,574-32,866)\end{array}$ \\
\hline Parkinson disease & $\begin{array}{c}1,792 \\
(1,592-1,999)\end{array}$ & $\begin{array}{c}2,063 \\
(1,724-2,847)\end{array}$ & $\begin{array}{c}1,406 \\
(964-1,927)\end{array}$ & $\begin{array}{c}2,261 \\
(1,590-3,112)\end{array}$ \\
\hline Epilepsy & $\begin{array}{c}18,091 \\
(16,356-20,090)\end{array}$ & $\begin{array}{c}9,222 \\
(7,904-10,923)\end{array}$ & $\begin{array}{c}43,099 \\
(25,837-63,429)\end{array}$ & $\begin{array}{c}35,604 \\
(21,666-53,415)\end{array}$ \\
\hline Multiple sclerosis & $\begin{array}{c}489 \\
(431-545)\end{array}$ & $\begin{array}{c}870 \\
(685-1,023)\end{array}$ & $\begin{array}{c}477 \\
(333-634)\end{array}$ & $\begin{array}{c}948 \\
(653-1,252)\end{array}$ \\
\hline Migraine & - & - & $\begin{array}{c}104,048 \\
(64,537-154,937)\end{array}$ & $\begin{array}{c}163,433 \\
(102,120-241,303)\end{array}$ \\
\hline Tensional Headache & - & - & $\begin{array}{c}5,465 \\
(2,592-10,036)\end{array}$ & $\begin{array}{c}9,043 \\
(4,222-16,531)\end{array}$ \\
\hline $\begin{array}{l}\text { Medication overuse for } \\
\text { headache }\end{array}$ & - & - & $\begin{array}{c}29,099 \\
(18,691-42,623)\end{array}$ & $\begin{array}{c}51,395 \\
(33,357-75,206)\end{array}$ \\
\hline Motoneuron disease & $\begin{array}{c}1,167 \\
(816-1,447)\end{array}$ & $\begin{array}{c}1,452 \\
(1,232-1,702)\end{array}$ & $\begin{array}{c}21 \\
(15-28)\end{array}$ & $\begin{array}{c}38 \\
(27-50)\end{array}$ \\
\hline Other neurological diseases & $\begin{array}{c}3,806 \\
(2,821-5,047)\end{array}$ & $\begin{array}{c}3,305 \\
(2,897-3,758)\end{array}$ & $\begin{array}{c}339 \\
(219-475)\end{array}$ & $\begin{array}{c}621 \\
(441-836)\end{array}$ \\
\hline
\end{tabular}

YLLs: years of life lost; YLDs: years lived with disability.

Table 3. Main causes of DALYs due to neurological diseases in Peru, 1990 and 2015.

\begin{tabular}{|c|c|c|}
\hline 1990 & 2015 & \\
\hline Disorder & Disorder & $\%$ Change \\
\hline 1 Migraine & 1 Migraine & $57 \%$ \\
\hline 2 Cerebrovascular disease & 2 Cerebrovascular disease & $-48 \%$ \\
\hline $\begin{array}{l}3 \text { Neonatal encephalopathy due to asphyxia or } \\
\text { trauma at birth }\end{array}$ & $\begin{array}{l}3 \text { Neonatal encephalopathy due to asphyxia } \\
\text { or trauma at birth }\end{array}$ & $-53 \%$ \\
\hline 4 Epilepsy & - 4 Alzheimer diseases and other dementias & $157 \%$ \\
\hline 5 Meningitis & 5 Medication overuse headache & $77 \%$ \\
\hline 6 Alzheimer diseases and other dementias & 6 Epilepsy & $-27 \%$ \\
\hline 7 Medication overuse headache & 7 Nervous system cancer & $183 \%$ \\
\hline 8 Encephalitis & 8 Meningitis & $-57 \%$ \\
\hline 9 Nervous system cancer & 9 Encephalitis & $-35 \%$ \\
\hline 10 Tensional Headache & 10 Tensional Headache & $65 \%$ \\
\hline 11 Parkinson disease & 11 Parkinson disease & $35 \%$ \\
\hline 12 Motoneuron disease & - 12 Multiple sclerosis & $88 \%$ \\
\hline 13 Multiple sclerosis & 13 Motoneuron disease & $25 \%$ \\
\hline
\end{tabular}


and Mexico, dementias represent the main factor that contributes to disability ${ }^{23}$. In Peru, Custodio et al. reported a prevalence of $6.85 \%$ of dementia in a population of 1,532 people over 65 years old in Lima, with Alzheimer's disease being the most frequent diagnosis ${ }^{24}$. Probable explanations for our findings would be the population aging, poor access to health services, low diagnostic capacity of dementia in primary care services, and the limited recognition of symptoms by family members and caregivers ${ }^{25}$.

The WHO reported that NE by asphyxia and trauma during childbirth are the seventh cause of BD worldwide ${ }^{26}$. Although the GBD studies show that, between 2005 and 2015, all causes of neonatal injury have decreased by $17.2 \%$ and,

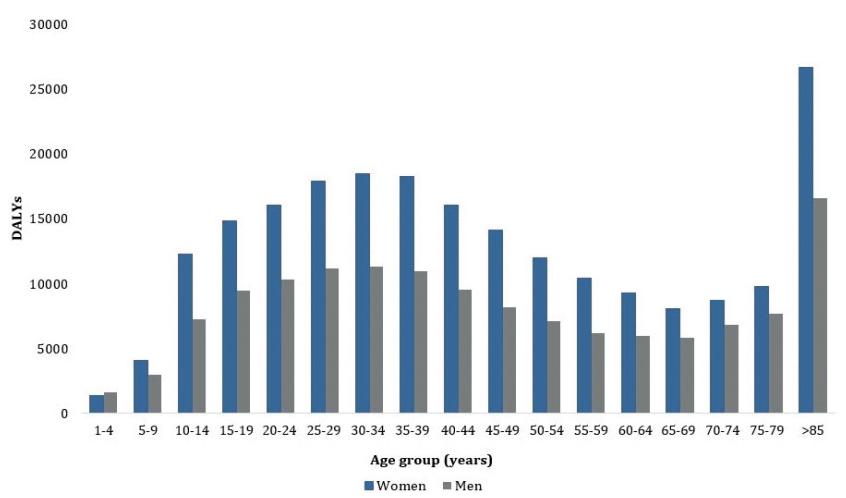

Figure 1. DALYs of neurological diseases in Peru, 2015, by gender and age group. among them, those due to NE by $14.6 \%$. In Peru, it was estimated that anoxia, asphyxia, and trauma at birth was the eighth cause of BD in 2004, representing 3\% of the total DALYs, mainly due to YLLs estimates $(83.7 \%)^{1}$. Our study also shows that between 1990 and 2015 there was a decrease in DALYs by NE, especially in its YLLs component, which is consistent with the global reports ${ }^{6}$. These results could be explained in Peru by the greater efforts to save premature newborn in the neonatal care rooms with health policy regulations ${ }^{27}$.

For epilepsy and PD, no increase in DALYs was reported globally between 1990 and 2015, which could be explained because these disorders are largely genetically determined ${ }^{6}$. However, in previous reports, between 1990 and 2010, the burden for the disability component (YLDs) of PD increased by $70.5 \%{ }^{18}$. Our results are consistent with the small reported prevalence of PD in Peru (6.71\% in a total of 1,340 people over 40 years old $)^{28}$. Epilepsy represents from 0.5 to $1 \%$ of DALYs in the world; about $80 \%$ of this burden would correspond to developing countries ${ }^{29}$. The United States and Canada have a burden corresponding to $0.4 \%$, lower than in Latin America and the Caribbean, countries in which it reaches up to $0.9 \%^{30}$. In Peru, a decrease in DALYs, of 27\%, was identified between 1990 and 2015 due to epilepsy, but still in the $6^{\text {th }}$ position among all neurological disorders, mainly due to the reported disability component. These results are supported by the reported high prevalence in some cities in the north of Peru $(17.25 \times 1,000)$, and it was also related to the higher number of neurocysticercosis cases ${ }^{31}$.

Figure 2: DALYs in Peru, 2015, neurological diseases and age group

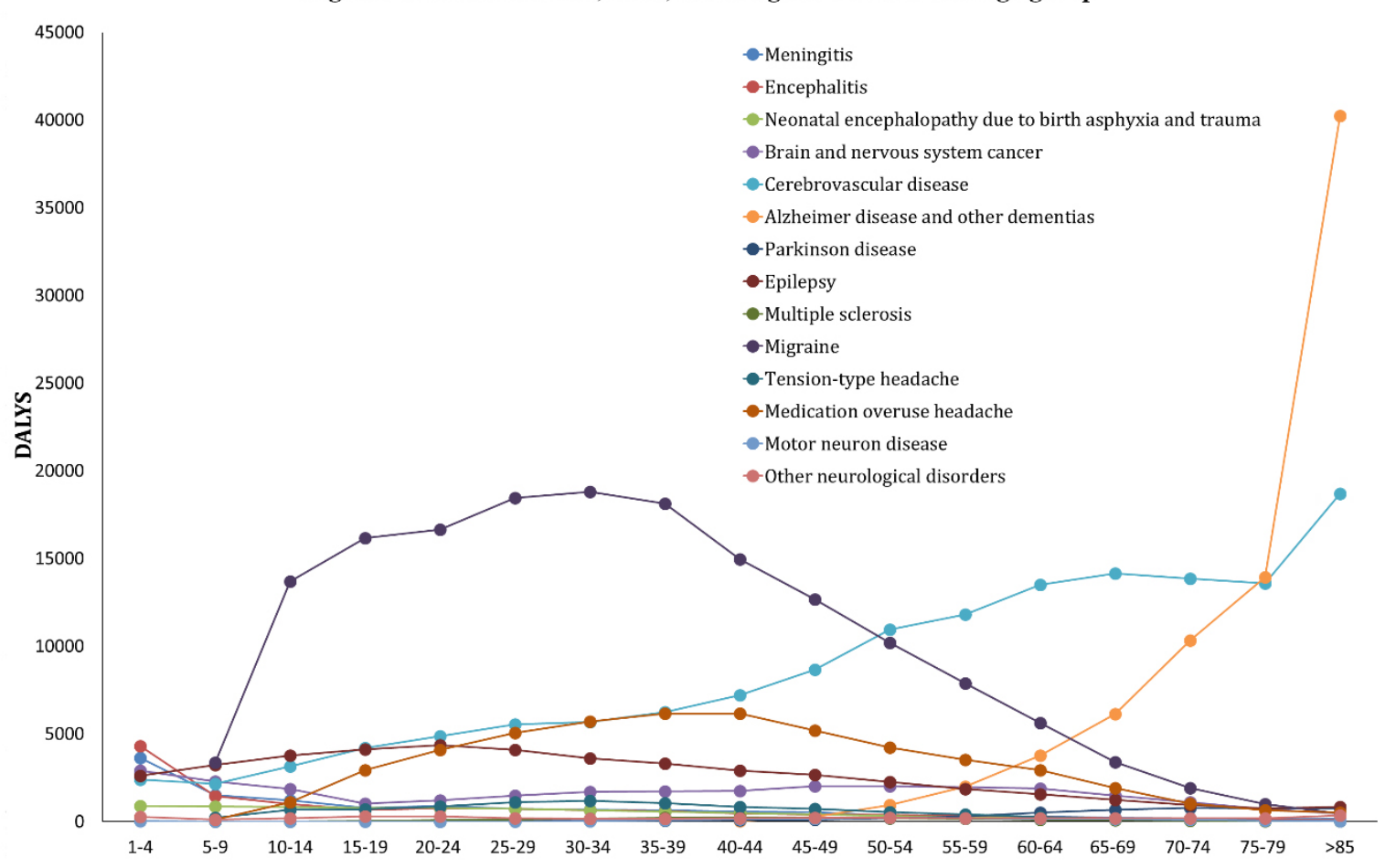

Figure 2. Disabilities-adjusted life year in Peru, 2015, neurological diseases by age group. 
DALYs due to ME also increased, but it is not clear whether this increase was due to improvements in the detection of cases or indicates a real increase in the prevalence of the disease $e^{6}$. These findings are consistent with the estimated low-mid-range prevalence of 7.69 per 100,000 inhabitants (95\% confidence interval 7.09 to 8.30 ) in Lima, clearly related to the improvement of cases detection due to greater health access in the capital of Peru ${ }^{32}$. Additionally, the decrease in the BD due to neurological infectious, such as meningitis (57\%) and encephalitis (37\%) is important; such decreases are consistent with what was reported for global DALY changes, both for meningitis $(31.9 \%)$ and encephalitis $(14 \%)^{5}$. This variation in Peru could be explained due to the impact of national vaccination programs and timely treatments of CNS infections that have improved in recent decades in Peru.

The main limitation of this systematic analysis is that it is a secondary source study, and we rely on the estimates made and made available in the database of the GBD 2015. These estimates may overestimate or underestimate the real prevalence or incidence in Peru. In addition, the data of the GBD has been recently updated until 2017; which explains why the estimates could have been modified. Nevertheless, our results could provide valuable information for decision-making processes and health resources allocations in Peru to modify the social determinants, risk factors, and reduce the $\mathrm{BD}$.
As it is in the whole world ${ }^{5}$, neurological disorders are a major cause of disability, death and have increased considerably over the last 25 years, probably due to populational growth and aging in countries. The largest proportion of this burden is produced by non-communicable neurological disorders, such as headaches, CVD, ADD, NE, and epilepsy. These disorders impact people of all age groups, from newborns and infants (such as NE and epilepsy) to young people and adults (due to headaches and migraine), as well as to older adults (due to CVD and ADD). Therefore, we consider that the number of patients who will need attention by specialists in neurological diseases will continue to grow in the upcoming decades. This increase should be considered for the design and application of health policies and strategies that can stop the progress and impact of this group of disorders in the global population, and health service providers should be aware of these trends to provide adequate services.

\section{CONCLUSION}

The BD increased by $1.6 \%$ from 1990 to 2015 . The main causes were migraine, CVD, and NE. ADD and NSC doubled their DALYs in this period. These diseases represent a significant cause of disability attributable to the increase in the life expectancy of our population, among other factors. Priority actions should be taken to prevent and treat these causes.

\section{References}

1. Velásquez A. La carga de enfermedad y lesiones en el Perú y las prioridades del plan esencial de aseguramiento universal. Rev Perú Med Exp Salud Publica. 2009 Apr/Jun;26(2):222-31.

2. Lopez AD, Mathers CD, Ezzati M, Jamison DT, Murray CJ. Global Burden of Disease and Risk Factors. Disease Control Priorities Project Washington: Washington (DC): The International Bank for Reconstruction and Development / The World Bank. New York: Oxford University Press; 2006.

3. Lopez AD, Mathers CD, Ezzati M, Jamison DT, Murray CJL. Global burden of disease and risk factors. New York: Oxford University Press; 2006.

4. Murray CJL. Cuantificación de la carga de enfermedad: la base técnica del cálculo de los años de vida ajustados en función de la discapacidad. Bol Oficina Sanit Panam. 1995;118(3):221-42.

5. GBD 2015 Neurological Disorders Collaborator Group. Global, regional, and national burden of neurological disorders during 1990-2015: a systematic analysis for the Global Burden of Disease Study 2015. Lancet Neurol. 2017 Nov;16(11):877-97. https://doi. org/10.1016/S1474-4422(17)30299-5

6. Bhagat NA, Venkatakrishnan A, Abibullaev B, Artz EJ, Yozbatiran $\mathrm{N}$, Blank AA, et al. Design and optimization of an EEG-Based Brain Machine Interface (BMI) to an upper-limb exoskeleton for stroke survivors. Front Neurosci. 2016 Mar;10:122. https://doi.org/10.3389/ fnins.2016.00122

7. World Health Organization. mhGAP intervention Guide (version 2.0) for mental, neurological and substance user disorders in non- specialized health settings. 2019. Available from: http://www.who. int/mental_health/mhgap/mhGAP_intervention_guide_02/en/.

8. Lara E, Garin N, Ferrari AJ, Tyrovolas S, Olaya B, Sànchez-Riera L, et al. La carga de la enfermedad en España 2010: trastornos neurológicos, mentales y re: trastornos neurológicos, mentales y relacionados con el consumo de sustancias. Rev Psiquiatr Salud Ment. 2015 Oct/Dec;8(4):207-17. https://doi.org/10.1016/j. rpsm.2014.09.001

9. Keynejad R, Dua T, Barbui C, Thornicroft G. WHO Mental Health Gap Action Programme (mhGAP) Intervention Guide: a systematic review of evidence from low and middle-income countries. Evid Based Ment Health. 2018 Feb;21(1):30-4. https://doi.org/10.1136/eb-2017102750

10. Coale AJ, Demeny P, Vaughan B. Regional model life tables and stable populations. $2^{\text {nd }}$ ed: New York: Academic Press; 1983.

11. Institute for Health Metrics and Evaluation. Protocol for the Global Burden of Diseases, Injuries, and Risk Factors Study (GBD). 2015.

12. Murray CJ, Ezzati M, Flaxman AD, Lim S, Lozano R, Michaud C, et al. GBD 2010: design, definitions, and metrics. Lancet. 2012 Dec;380(9859):2063-6. https://doi.org/10.1016/S01406736(12)61899-6

13. Budosan B, O'Hanlon KP, Mahoney J, Aziz S, Kesavan R, Beluso K. Up scaling mental health and psychosocial services in a disaster context: Lessons learnt from the Philippine Region hardest hit by typhoon Haiyan. Int J Med Med Sci. 2016 Oct;8(10):112-9. https://doi. org/10.5897/IJMMS2016.1263 
14. Spagnolo J, Champagne F, Leduc N, Piat M, Melki W, Charfi F, et al. Building system capacity for the integration of mental health at the level of primary care in Tunisia: a study protocol in global mental health. BMC Health Serv Res. 2017 Jan;17:38. https://doi. org/10.1186/s12913-017-1992-y

15. Crowley RA, Kirschner N, Health and Public Policy Committee of the American College of Physicians. The integration of care for mental health, substance abuse, and other behavioral health conditions into primary care: executive summary of an American College of Physicians position paper. Ann Intern Med. 2015 Aug;163(4):298-9. https://doi.org/10.7326/M15-0510

16. Jaillard AS, Mazetti P, Kala E. Prevalence of migraine and headache in a high-altitude town of Peru: a population-based study. Headache. 1997 Feb;37(2):95-101. https://doi.org/10.1046/j.15264610.1997.3702095.x

17. Feigin VL, Krishnamurthi RV, Parmar P, Norrving B, Mensah GA, Bennett DA, et al. Update on the Global Burden of Ischemic and Hemorrhagic Stroke in 1990-2013: The GBD 2013 Study. Neuroepidemiology. 2015 Oct;45(3):161-76. https://doi. org/10.1159/000441085

18. Vos T, Flaxman AD, Naghavi M, Lozano R, Michaud C, Ezzati M, et al. Years lived with disability (YLDs) for 1160 sequelae of 289 diseases and injuries 1990-2010: a systematic analysis for the Global Burden of Disease Study 2010. The Lancet. 2012 Dec;380(9859):2163-96. https://doi.org/10.1016/S0140-6736(12)61729-2

19. Barker-Collo S, Bennett DA, Krishnamurthi RV, Parmar P, Feigin VL, Naghavi M, et al. Sex differences in stroke incidence, prevalence, mortality and disability-adjusted life years: results from the Global Burden of Disease Study 2013. Neuroepidemiology. 2015 Oct;45(3):203-14. https://doi.org/10.1159/000441103

20. Atamari-Anahui N, Alva-Diaz C, Vera-Monge V, Taype-Rondan A. Tendencia de mortalidad por enfermedad cerebrovascular registrada por el Ministerio de Salud de Perú, 2005-2015. Neurol Arg. 2019 Oct/ Dec;11(4):202-9. https://doi.org/10.1016/j.neuarg.2019.07.001

21. Olfson M. The rise of primary care physicians in the provision of US mental health care. J Health Polit Policy Law. 2016 Aug;41(4):559-83. https://doi.org/10.1215/03616878-3620821

22. Custodio N, Wheelock A, Thumala D, Slachevsky A. Dementia in Latin America: epidemiological evidence and implications for public policy. Front Aging Neurosci. 2017 Jul;9:221. https://doi.org/10.3389/ fnagi.2017.00221

23. Sousa RM, Ferri CP, Acosta D, Albanese E, Guerra M, Huang Y, et al. Contribution of chronic diseases to disability in elderly people in countries with low and middle incomes: a 10/66 Dementia Research Group population-based survey. Lancet. 2009 Nov 28;374(9704):1821-30. https://doi.org/10.1016/S01406736(09)61829-8

24. Custodio N, García A, Montesinos R, Escobar J, Bendezú L. Dementia prevalence in a Lima, Peru urban community: door-to-door study. An Fac Med. 2008 Dec;69(4):233-8.

25. Parra MA, Baez S, Allegri R, Nitrini R, Lopera F, Slachevsky A, et al. Dementia in Latin America: Assessing the present and envisioning the future. Neurology. 2018 Jan;90(5):222-31. https://doi. org/10.1212/WNL.0000000000004897

26. Organización Mundial de la Salud. Informe sobre la salud en el mundo 2003: Forjemos el futuro. Ginebra, Suiza: OMS; 2003.

27. Khoja S, Scott R, Husyin N, Durrani H, Arif M, Faqiri F, et al. Impact of simple conventional and Telehealth solutions on improving mental health in Afghanistan. J Telemed Telecare. 2016 Dec;22(8):495-8. https://doi.org/10.1177/1357633X16674631

28. Ramírez LT, Quispe LM, Jara MC, Calderón JD, Cabanillas MM, Henríquez JM, et al. Prevalencia de la enfermedad de Parkinson: un estudio puerta a puerta en cinco distritos de Ulcumayo- Junín-Perú. DIAGNOSTICO. 2007 Oct;47(4):150-6.

29. Aarli JA, Dua T, Janca A, Muscetta A. Trastornos neurológicos: desafíos para la salud pública. Ginebra, Suiza: Organización Mundial de la Salud; 2006. Available from: http://www1.paho.org/hq/ dmdocuments/2008/Trastornos_Neurologicos.pdf

30. Informe sobre la Epilepsia en Latinoamérica. Panamá: Liga Internacional contra la Epilepsia, Buró Internacional de Epilepsia y Organización Mundial de la Salud. 2008. Available from: http://new. paho.org/hq/dmdocuments/2008/Informe_sobre_epilepsia.pdf

31. Moyano LM. Epidemiologia de la epilepsia en el Peru: Neurocisticercosis como causa de epilepsia secundaria en la region norte del Peru. Human health and pathology. Université de Limoges, 2016.

32. Darwin VE, Jorge KC, Carlos CB, Ana CG, Martin TB, Antonio BO, et al. Prevalencia de Esclerosis Múltiple en Lima - Perú. Rev Med Hered. 2009 Jul;20(3):146-50. 